\title{
Increased Fetal Plasma and Amniotic Fluid Erythropoietin Concentrations: Markers of Intrauterine Hypoxia
}

\author{
Kari A. Teramo ${ }^{a}$ John A. Widness ${ }^{b}$ \\ a Department of Obstetrics and Gynecology, University Central Hospital, Helsinki, Finland; b Department of \\ Pediatrics, Roy J. and Lucille A. Carver College of Medicine, University of lowa, lowa City, lowa, USA
}

\section{Key Words}

Erythropoietin $\cdot$ Cord blood $\cdot$ Amniotic fluid $\cdot$ Hypoxia $\cdot$ Neuroprotection

\begin{abstract}
Tissue hypoxia is the major stimulus of erythropoietin (EPO) synthesis in fetuses and adults. Since EPO does not cross the placenta and is not stored, fetal plasma and amniotic fluid levels indicate EPO synthesis and elimination. Acutely, the rate and magnitude of the increase in plasma EPO levels correlate with the intensity of hypoxia. Amniotic fluid EPO levels correlate with cord plasma levels in normal and abnormal pregnancies, with fetal plasma EPO levels in humans averaging 2.6 times higher than the corresponding amniotic fluid EPO levels. Recent experimental and clinical studies demonstrate that EPO has neuroprotective effects related to its anti-apoptotic and vascular growth-promoting properties. Although under basal conditions the fetal kidneys are the main site of EPO production, during hypoxia recent experimental data indicate an important role of the placenta. Amniotic fluid EPO levels have been shown to increase exponentially during fetal hypoxia in preeclamptic, diabetic and $\mathrm{Rh}$-immunized pregnancies, to correlate inversely with cord blood $\mathrm{pH}, \mathrm{pO}_{2}$ and base excess and to predict neonatal morbidities and NICU admission. As an indicator of chronic intra-
\end{abstract}

uterine hypoxia, fetal EPO measurements have increased our knowledge about the pathogenesis and importance of intrauterine growth restriction, macrosomia, diabetic pregnancy, prolonged pregnancy, meconium staining, fetal hemorrhage, fetal anemia, maternal smoking and alcohol consumption, abnormal fetal heart rate and abnormal Doppler flow patterns. While the clinical utility of fetal amniotic fluid and plasma EPO measurements in the management of highrisk pregnancies and their offspring is promising, adequately powered clinical trials are urgently needed.

Copyright $\odot 2008$ S. Karger AG, Basel

\section{Introduction}

Hypoxia is the major stimulus of ery thropoietin (EPO) synthesis in both the fetus and adult. In this review the importance of fetal EPO production in normal and abnormal pregnancies will be discussed based on experimental and clinical studies. Since recent studies have shown that EPO has neuroprotective properties in addition to its role in the regulation of erythropoiesis, the possible importance of the non-erythropoietic effects of EPO in the fetus will be reviewed.

Also included in this review is a discussion of the potential clinical use of fetal plasma and amniotic fluid EPO

\section{KARGER}

๑) 2008 S. Karger AG, Basel

Fax +41613061234 E-Mail karger@karger.ch www.karger.com www.karger.com/neo
Kari A. Teramo, MD, PhD, Senior Scientist

Department of Obstetrics and Gynecology

University Central Hospital, Haartmanninkatu 2

FI-00290 Helsinki (Finland)

Tel. +358 50427 9519, Fax +3589471 65571, E-Mail kari.teramo@hus.fi 
measurements in evaluating the presence or absence of intrauterine hypoxia and subsequent neonatal outcome. This information is important because of a continuing urgent need to identify new methods for assessing anteand peripartum fetal well-being. Limited data suggest that plasma and amniotic fluid EPO measurements may have advantages over other perinatal predictors of clinical outcomes.

\section{Conditions Affecting Fetal Plasma EPO Concentrations}

During early development of the embryo EPO is first synthesized in the yolk sac and later in the liver and finally in the peritubular interstitial cells of the kidneys [1, 2]. At term the main fetal production site of EPO is in the kidneys [3], but during hypoxia EPO is produced also in other sites of the fetus. Human fetuses with renal agenesis have normal or elevated cord plasma EPO levels and normal hematocrit levels at birth [4], indicating that the kidneys are not necessary for fetal EPO production.

The interpretation of EPO levels in the fetus is dependent on an understanding of processes that contribute to the kinetics of EPO in the fetus and its intravascular and amniotic fluid compartments. With the exception of murine species where less than $10 \%$ of maternal EPO traverses the placenta, EPO has not been shown to cross the placenta in either direction [5]. This observation along with the finding that EPO is not stored in tissues for later release indicate that fetal plasma EPO levels are indicative of acute fetal EPO production and elimination.

The half-life of EPO in the blood of human adults is 4-8 h [6] compared to 2-4 h in newborn infants [7]. Although the half-life of EPO in the human fetus is unknown, in the sheep a progressive shortening of EPO half-life is observed from adults to newborn lambs to late gestation fetuses [8].

In human adults plasma EPO levels start to increase approximately $90 \mathrm{~min}$ after the induction of acute hypoxia [9]. These human studies also demonstrated that the rate and magnitude of the increase in plasma EPO levels correlate with the severity of hypoxia [9]. Because experimental induction of fetal hypoxia in humans is precluded for obvious ethical reasons, experimental and in vitro studies have contributed considerably to our understanding of EPO production and elimination within the fetal compartment. Acute experiments in near-term rats and sheep have demonstrated that EPO levels in fetal plasma start to increase within 2-3 h after the beginning of mod- erate to severe fetal hypoxia $[1,10,11]$. In contrast, the induction of chronic mild hypoxia in fetal sheep over a period of several days results in an initial increase in plasma EPO levels, after which levels decrease to a steadystate level slightly above that prior to the hypoxic period [12].

In uncomplicated term human pregnancies with vigorous newborn infants, EPO levels in umbilical cord blood at birth are higher after uncomplicated vaginal deliveries than after elective cesarean sections without labor contractions [13]. This suggests that even normal labor and vaginal delivery results in sufficient fetal tissue hypoxia to stimulate fetal EPO synthesis, but it can also be a physiologic process, which could improve the adaptation of the fetus to extrauterine life. Regular exercise among healthy women during the last weeks of pregnancy does not increase fetal EPO production as indicated by normal fetal amniotic fluid EPO levels [14]. This suggests that even strenuous exercise during normal pregnancy does not decrease oxygen delivery to the fetus.

Median or mean cord plasma EPO levels from uncomplicated term pregnancies before the onset of labor range between 20 and $35 \mathrm{mU} / \mathrm{ml}$ with the upper limit of normal ranging between 50 and $60 \mathrm{mU} / \mathrm{ml}$ [15-18]. Most studies have reported that during the latter half of pregnancy during normal stable conditions fetal plasma EPO levels do not change $[13,16,18,19]$. The large study by Forestier et al. [18] is particularly important in this regard. These investigators measured plasma EPO levels from cord blood obtained by percutaneous sampling between 18 and 37 weeks of gestation in 163 healthy fetuses. Plasma EPO levels did not correlate with gestational age. In some studies fetal plasma EPO levels have been observed to increase 2- to 4 -fold between midgestation and term $[17,20-22]$. This apparent rise in plasma EPO as pregnancy progresses could be explained by inclusion of cord EPO levels obtained after the onset of labor or from highrisk pregnancies with hypoxic fetuses.

Finne [23] was the first to show increased EPO levels in cord blood and amniotic fluid in pregnancies complicated by preeclampsia or diabetes. He measured EPO concentrations with an in vivo mouse bioassay, which required several milliliters of sample for even a single measurement. Subsequently, a radioimmunoassay method was developed for EPO measurements, which required sample volumes of $0.2 \mathrm{ml}$ but took a full day to assay [24]. More recently, results of EPO measurements can be obtained reliably within $4 \mathrm{~h}$, e.g., by a chemiluminescent enzyme-labeled immunometric assay. 


\section{Conditions Affecting Amniotic Fluid EPO Concentration}

In humans, EPO is found in the extra-embryonic coelomic fluid and in the amniotic fluid as early as 7 weeks of gestation [25]. Amniotic fluid EPO concentrations correlate well with simultaneously obtained cord plasma EPO levels before uterine labor contractions both in normal and abnormal human pregnancies [16, 26-28]. It is therefore possible to follow fetal plasma EPO levels antenatally by repeated measurements of EPO in the amniotic fluid. Amniotic fluid EPO levels obtained 1 or 2 days before labor by cesarean section also correlate well with fetal cord plasma EPO levels at birth in pregnancies complicated by hypertension or diabetes $[28,29]$.

In human pregnancy, fetal plasma EPO levels are approximately 2.6 times higher than the corresponding concentration in the amniotic fluid. This is true both during normal steady-state conditions when amniotic fluid levels are $<20 \mathrm{mU} / \mathrm{ml}$ and during severe fetal hypoxia when amniotic fluid levels are $>50 \mathrm{mU} / \mathrm{ml}$ [16], but not when the amniotic fluid EPO levels are intermediate to those values (fig. 1) [30]. This lack of correlation is likely due to the delay in the increase in EPO concentration in the amniotic fluid compared with the increase in fetal plasma. In contrast, in ovine pregnancy amniotic fluid and fetal plasma EPO levels correlate only weakly during stable non-hypoxic conditions [31]. During severe fetal hypoxia in the sheep, amniotic fluid EPO concentrations doubled after $12 \mathrm{~h}$, although fetal plasma EPO levels increased by a factor of nearly 30 during the same time period [31]. Thus, it appears that the kinetic behavior of EPO into the amniotic fluid is different in sheep compared to humans. Alternatively, this could also indicate that the synthesis and function of EPO in the placenta, fetal membranes and amniotic fluid are different in humans and sheep. In normal human pregnancies without signs of fetal hypoxia, amniotic fluid EPO levels remain unchanged between midgestation and term $[16,26]$. Amniotic fluid EPO levels obtained at delivery by elective cesarean section from healthy vigorous term fetuses range from 2 to 19 (median 6.3-7.5) $\mathrm{mU} / \mathrm{ml}[16,28]$.

It is unclear how EPO reaches the amniotic fluid and whether EPO has any functional effects in the amniotic fluid. EPO along with its receptor and EPO mRNA are all present in both ovine and human fetal membranes in the latter half of pregnancy [32-35]. Hence, the chorion or amnion, or both, are likely the source of amniotic fluid EPO. Since EPO is present in urine, it too is a contributor to amniotic fluid EPO. Based on available data, uri-

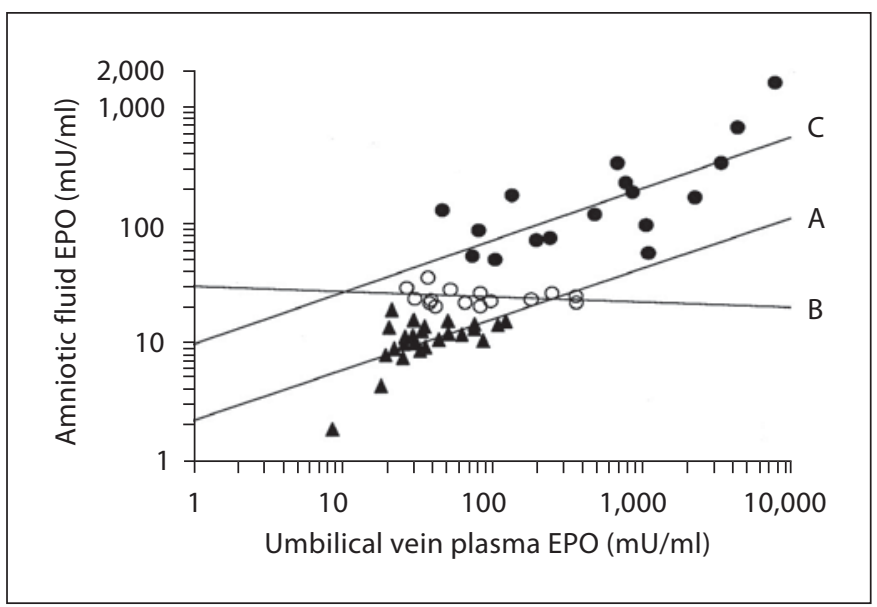

Fig. 1. Fifty-eight pregnancies complicated by preeclampsia or hypertension grouped into low $(<20 \mathrm{mU} / \mathrm{ml}$, regression line $\mathrm{A}, \mathrm{r}=$ $0.87, \mathrm{p}<0.0001, \mathrm{n}=28)$ and high $(>50 \mathrm{mU} / \mathrm{ml}$, regression line $\mathrm{C}$, $\mathrm{r}=0.86, \mathrm{p}<0.0001, \mathrm{n}=17$ ) amniotic fluid EPO levels correlate with cord plasma EPO levels obtained simultaneously at cesarean section. Slightly elevated amniotic fluid EPO levels (20-50 mU/ $\mathrm{ml}$, regression line $\mathrm{B}, \mathrm{r}=-0.10, \mathrm{n}=13$ ) do not correlate with cord plasma EPO levels. Reproduced with permission from Teramo [30].

nary EPO excretion does not appear to be of sufficient magnitude to explain the high amniotic fluid EPO levels measured during fetal hypoxia in either human $[28,29]$ (fig. 2) or sheep pregnancy [31]. Sequential amniotic fluid EPO measurements in preeclamptic and diabetic pregnancies have revealed that EPO levels can increase exponentially during fetal hypoxia (fig. 2) [28, 29]. Similar exponential increases in amniotic fluid levels have been reported in pregnancies complicated by $\mathrm{Rh}$ immunization in fetuses with severe hypoxia [26]. Among high-risk pregnancies, daily increases in amniotic fluid EPO levels can be as much as $22-25 \mathrm{mU} / \mathrm{ml}[28,29]$.

During acute hypoxia in the rat, amniotic fluid EPO levels start to increase $6 \mathrm{~h}$ after fetal serum levels [11]. In this study fetal serum EPO levels returned to normal 12$48 \mathrm{~h}$ after ending of hypoxia, while amniotic fluid EPO levels remained elevated during the same time period [11]. During vaginal delivery in humans, amniotic fluid EPO levels start to increase $6 \mathrm{~h}$ after the fetal membranes have been ruptured [14]. These studies indicate that fetal EPO levels start to increase several hours later in the amniotic fluid compared to plasma.

Amniotic fluid EPO levels in humans remain elevated after the fetus dies from a chronic cause [36]. If the fetus dies from an acute cause, e.g., acute total placental abruption or severe cord entanglement, amniotic fluid EPO 
Fig. 2. Seventy-five pregnancies complicated by hypertension grouped into low amniotic fluid ( $<20 \mathrm{mU} / \mathrm{ml}, \mathrm{n}=38$, group $1)$, intermediate amniotic fluid (20.0-71.2 $\mathrm{mU} / \mathrm{ml}, \mathrm{n}=19$, group 2) and high amniotic fluid EPO levels ( $>71.2 \mathrm{mU} / \mathrm{ml}, \mathrm{n}=18$, group 3). The lower horizontal dotted line represents the upper range of healthy control pregnancies $(19.1 \mathrm{mU} / \mathrm{ml})$ and the upper horizontal dotted line represents $8 \times$ the median of controls $(71.2 \mathrm{mU} / \mathrm{ml})$. Serial amniotic fluid samples from the same patient are connected by lines. Fetal and neonatal data of group 1 (normal EPO) and group 3 (high EPO) are given in table 1 under Hypertensive pregnancies. Reproduced with permission from Teramo et al. [29].

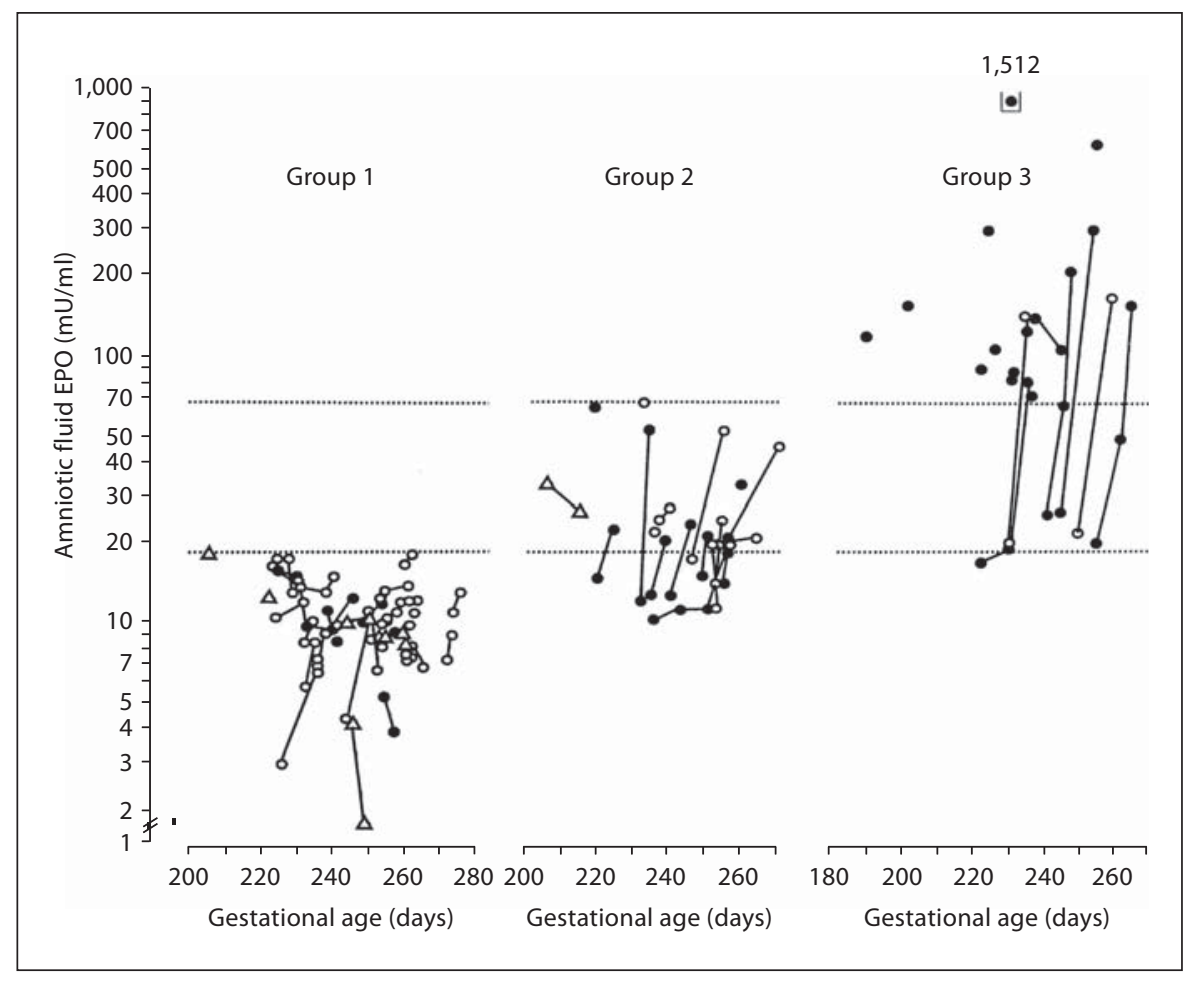

levels are not increased. This suggests that the fetal demise was so acute that amniotic fluid EPO did not have sufficient time to increase. Thus, by measuring the amniotic fluid EPO level after fetal death, it is possible to determine whether the fetus died from an acute or a chronic cause [36]. While a decline in amniotic fluid EPO levels following fetal demise may occur as a result of metabolic EPO degradation, in vitro experiments conducted at $37^{\circ} \mathrm{C}$ have demonstrated that endogenous EPO levels in amniotic fluid decrease slowly and linearly (i.e., only by one third from its initial concentration in 3 weeks) [37]. It can therefore be assumed that the amniotic fluid EPO levels were higher at the time of the fetal death than at the time of the subsequent amniotic fluid sampling.

\section{Fetal Adaptation to Chronic Hypoxia}

Oxygenation of fetal tissues depends on normal maternal oxygenation and the ability of the placenta to deliver an adequate supply of oxygen from the maternal to the fetal circulation. Fetal circulation adapts to decreased oxygen delivery by redistributing cardiac output. Hypoxia also stimulates EPO synthesis in the fetus resulting in an increase in fetal erythrocyte production [38] and in an increase in the oxygen-carrying capacity. For additional details describing the role of EPO in regulating fetal erythropoiesis, see the reviews by Vora and Gruslin [39] and Widness and Teramo [40].

An increase in the number of nucleated red blood cells (NRBCs) is an indicator of increased red cell production. The NRBC level in cord blood at birth is used clinically to evaluate hypoxic events in utero $[41,42]$. Because the increase in the hematocrit from acute or chronic hypoxic events is a relatively slow process, a high NRBC level in cord blood at birth is considered indicative of hypoxic events that have occurred before the onset of labor [43]. EPO is the trigger for the increased erythropoiesis and, as expected, the NRBClevel in cord blood has been shown to correlate directly with cord plasma EPO levels at birth [44].

\section{Regulation of Fetal EPO Synthesis during Hypoxia}

Only a few years ago it became clear that tissue oxygenation is regulated locally by the transcription factor hypoxia-inducible factor (HIF-1) [45]. It is well established that HIF- $1 \alpha$ is involved in several key processes necessary for maintaining adequate tissue oxygenation 
$[45,46]$. Unlike during normoxia when HIF- $1 \alpha$ is inactivated by the ubiquitin system, during hypoxia HIF-1 $\alpha$ becomes activated, stimulating both EPO and vascular endothelial growth factor production [47].

By measuring renal venous and arterial plasma EPO differences and renal blood flow in fetal sheep near term, Davis et al. [48] showed that the kidneys are the main site of EPO synthesis during normoxia, during which no EPO production could be observed in the placenta. During hypoxia, however, these investigators observed a marked switch of the primary site of fetal EPO synthesis from the kidneys to the placenta. During moderate to severe fetal hypoxia the placenta was estimated to produce EPO at $1.1 \times 10^{6} \mathrm{mU} / \mathrm{h}$, a production rate 15 times greater than that of the fetal kidneys [48].

\section{Fetal Erythropoietin Levels in Pregnancies at High Risk of Fetal Hypoxia}

\section{Correlation with Umbilical Artery pH, Base Excess,}

\section{Lactate, and Blood Gases}

Fetal plasma and amniotic fluid EPO levels increase regardless of the etiology of fetal hypoxia. Several studies have shown that both umbilical plasma and amniotic fluid EPO levels at birth correlate inversely with umbilical artery $\mathrm{pH}$, base excess and $\mathrm{pO}_{2}$ and directly with $\mathrm{pCO}_{2}$ and lactate $[16,28,49-52]$. In the fetal sheep when the oxygen content falls below $60 \%$ of basal levels in arterial blood, plasma EPO levels increase exponentially [53]. Similarly, in human pregnancies complicated by type- 1 diabetes, amniotic fluid EPO levels increase exponentially when the umbilical artery $\mathrm{pO}_{2}$ levels decrease below 2.0 $\mathrm{kPa}$ (fig. 3) [28].

\section{Correlation with Fetal Iron Status}

Intrauterine chronic hypoxemia, commonly observed among growth-restricted fetuses and among fetuses of insulin-treated diabetic mothers, stimulates fetal EPO production which in turn increases red blood cell production. Because the accelerated hemoglobin synthesis requires increased amounts of iron, fetal iron is preferentially diverted away from fetal tissue stores to red blood cell production $[54,55]$. The zinc protoporphyrin/heme ratio, an indicator of fetal iron status, has been correlated directly with fetal plasma EPO levels at birth [56]. This suggests that fetal chronic hypoxemia associated with pregnancies of women with diabetes and those carrying growth-retarded fetuses may be the cause of fetal tissue iron deficiency, and possibly of subsequent abnormal

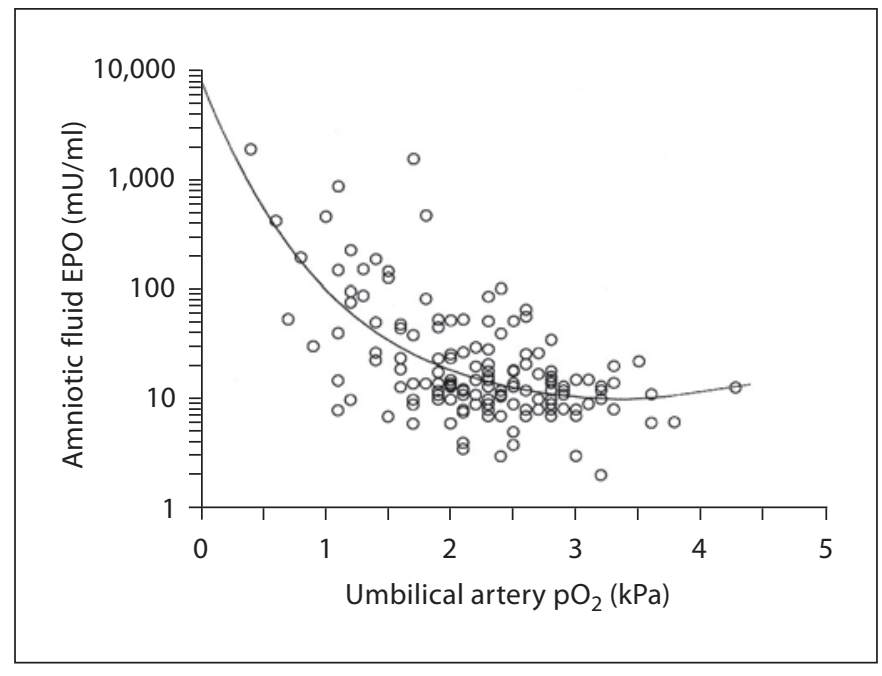

Fig. 3. Logarithmically transformed last amniotic fluid EPO concentration obtained 1 day (median) before delivery by cesarean section correlates negatively with umbilical artery $\mathrm{pO}_{2}$ in type- 1 diabetic pregnancies. Reproduced with permission from Teramo et al. [28].

neurodevelopmental outcomes reported in their offspring [57].

\section{Prolonged Pregnancy and Meconium Staining of the \\ Amniotic Fluid \\ Cord plasma EPO levels at birth increase progressive-} ly after 40 weeks of gestation in pregnancies with spontaneous onset of labor [58]. This is in agreement with the concept that in some pregnancies beyond 40 weeks gestation placental function starts to deteriorate, thereby favoring close fetal surveillance in prolonged post-term pregnancies.

Meconium staining of amniotic fluid has been a controversial marker of intrauterine hypoxia. In support of the association of meconium and fetal hypoxemia are studies showing that fetal plasma EPO levels are increased at birth independent of gestational age in pregnancies with meconium-stained amniotic fluid [59-61].

\section{Intrauterine Growth Restriction}

Cord plasma and amniotic fluid EPO levels are frequently elevated in growth-restricted fetuses [29, 62-64]. In pregnancies complicated by preeclampsia, intrauterine growth restriction is often a result of placental insufficiency and presumed fetal hypoxia. Thus, it is not surprising that amniotic fluid EPO levels correlate inversely with the birth weight adjusted for gestational age in preg- 


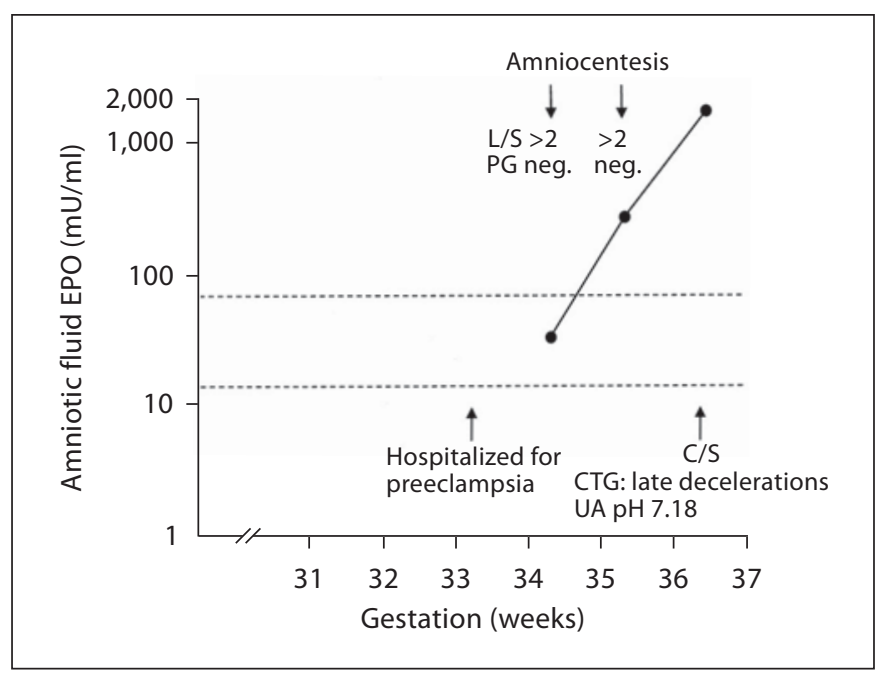

Fig. 4. Exponentially increasing amniotic fluid EPO level in a White's class $\mathrm{C}$ diabetic with poor glycemic control during the last trimester (HbAlc ranged from 8.4 to $8.8 \%$ ). The patient was hospitalized for preeclampsia during the 34 th gestational week. She had two amniocenteses done for fetal lung maturity evaluation at $34^{2} / 7$ and $35^{2} / 7$ gestational weeks. Amniotic fluid EPO levels were not known to the clinicians. An emergency cesarean section was performed at $36^{3} / 7$ weeks of gestation because of late decelerations in the fetal heart rate recording. Umbilical artery $\mathrm{pH}$ was 7.18 at birth. L/S = Lecithin/sphingomyelin ratio; $\mathrm{PG}=$ phosphatidylglycerol; C/S = cesarean section; CTG = cardiotocography.

nancies with growth-restricted fetuses $[29,65]$. In this regard it is noteworthy that, in twins with discordant growth, the smaller, and presumably more hypoxic, twin has higher EPO levels $[66,67]$. Monochorionic twin fetuses more often have elevated serum EPO levels compared to dizygotic twins [67].

As is well recognized from high-altitude pregnancies, chronic hypoxia results in decreased fetal growth. In a recent study, maternal circulating EPO concentrations and EPO receptor density in the syncytial microvilli were both increased, but the density of the glucose transporter GLUT-1 in the syncytial microvilli was decreased in high-altitude pregnancies [68]. Thus, chronic hypoxia seems to reduce fetal growth by reducing both oxygen and nutrient delivery to the fetus.

\section{Abnormal Fetal Heart Rate Recordings}

Abnormal fetal heart rate recordings during labor have been correlated with cord plasma EPO levels at birth in both appropriately grown and growth-restricted fetuses $[64,69,70]$. The highest fetal EPO levels occur in cases with the most abnormal fetal heart rate patterns during the last $4 \mathrm{~h}$ of labor [69]. Cord plasma and amniotic fluid EPO levels at delivery are higher in those delivered by emergency cesarean section for abnormal fetal heart rate recordings before the onset of labor than in those with normal fetal heart rate recordings and elective cesarean section delivery [70]. Serial amniotic fluid EPO measurements have demonstrated that in individual high-risk pregnancies EPO levels start to increase several days before abnormal fetal heart rate changes are observed (fig. 4) $[28,29]$.

\section{Nuchal Cord}

Cord entanglement is observed in up to $35 \%$ of newborn infants at birth and it is a potential risk factor for the subsequent development of cerebral palsy and delayed neurodevelopment [71]. In a recent study, Hashimoto and Clapp [72] observed that amniotic fluid EPO levels obtained either at amniotomy for induction of labor or during labor via a uterine catheter were higher in pregnancies in which the umbilical cord was around the neck of the fetus at birth compared with pregnancies without a nuchal cord. Cord plasma EPO levels did not differ between the groups at birth. The authors suggested that nuchal cord is a mild, but independent risk factor for chronic fetal hypoxia before labor. The elevated amniotic fluid EPO levels in pregnancies with a nuchal cord could indicate that these fetuses had experienced one or more chronic antepartum hypoxic episodes, since it is known that amniotic fluid EPO levels remain elevated [11] or decrease only slowly [37] while fetal plasma EPO levels decrease within hours [11] after recovery from transient hypoxic episodes.

\section{Abnormal Fetal Doppler Flow}

Umbilical artery and fetal ductus venosus Doppler flow measurements are widely used clinically to evaluate hemodynamic function especially in growth-restricted fetuses. In a recent study on growth-restricted fetuses with birth weight $\mathrm{z}$-scores below $-2.0 \mathrm{SD}$, cord serum EPO levels at birth were increased in direct association with the severity of the fetal hemodynamic compromise [73]. Cord serum EPO levels were significantly higher in fetuses with an abnormal ductus venosus blood velocity waveform pattern than in fetuses with either a normal or an abnormal umbilical artery blood velocity waveform pattern but a normal ductus venosus flow pattern.

\section{Diabetic Pregnancies}

Intrauterine hypoxic complications are clearly increased and 'unexplained' fetal deaths still occur during 
the last weeks of diabetic pregnancies $[28,74,75]$. The finding that iron stores in the liver and the brain are completely depleted in most fetuses who die in utero indicates that the majority of stillbirths of diabetic mothers is preceded by a period of chronic fetal hypoxia in which iron is diverted away from tissues in favor of red blood cell production $[54,55]$. Although the exact mechanisms of fetal hypoxia in diabetic pregnancies are not fully understood, several factors which occur in combination or alone can result in decreased delivery of oxygen to the fetus of diabetic mothers [76]. Experimental and human studies have shown that both fetal hyperglycemia and hyperinsulinemia can independently result in fetal hypoxemia [53, 77-79]. In type-1 diabetic mothers HbAlc levels during the last month of pregnancy correlate positively with concurrent fetal plasma and amniotic fluid EPO levels $[28,79]$. These observations emphasize the importance of maintaining adequate glycemic control throughout pregnancy.

Amniotic fluid EPO measurements in type-1 diabetic pregnancies have revealed a U-shaped correlation between the birth weight $\mathrm{z}$-score and the amniotic fluid EPO levels [28]. Above $+1.0 \mathrm{SD}$ units the correlation is positive, but below $-0.6 \mathrm{SD}$ units it is clearly negative. Thus, it appears that the optimal birth weight of fetuses of diabetic mothers is quite narrow (i.e., from -0.6 to +1.0 SD units). This new observation suggests that fetuses of type-1 diabetic mothers with a birth weight $\mathrm{z}$-score below $-0.6 \mathrm{SD}$ units should be considered as 'growth-restricted' and possibly suffering from chronic hypoxia. If this observation can be confirmed by other studies, it has important clinical consequences in the management of diabetic pregnancies.

\section{Acute Fetal Hemorrhage}

In the study by Kim et al. [80], plasma EPO concentrations increased 3-4 $\mathrm{h}$ after an acute massive hemorrhage in fetal sheep. This is similar to the increase in fetal plasma EPO levels observed after induction of severe fetal hypoxia by reducing oxygen delivery to fetal tissues [10]. Maximal fetal EPO concentrations that were 30-40 times above the basal levels were reached $16 \mathrm{~h}$ after the removal of $40 \%$ of the estimated fetal blood volume over $2 \mathrm{~h}$. Subsequent fetal plasma EPO levels decreased rapidly despite persistent fetal anemia [80]. In this study the plasma EPO concentration correlated inversely with fetal hematocrit, but not with $\mathrm{pO}_{2} 6 \mathrm{~h}$ after the acute hemorrhage despite a decrease in mean $\mathrm{pO}_{2}$ from 20 to $14.5 \mathrm{~mm} \mathrm{Hg}$. In a stillbirth case due to massive feto-maternal hemorrhage, the amniotic fluid EPO level was not increased 3

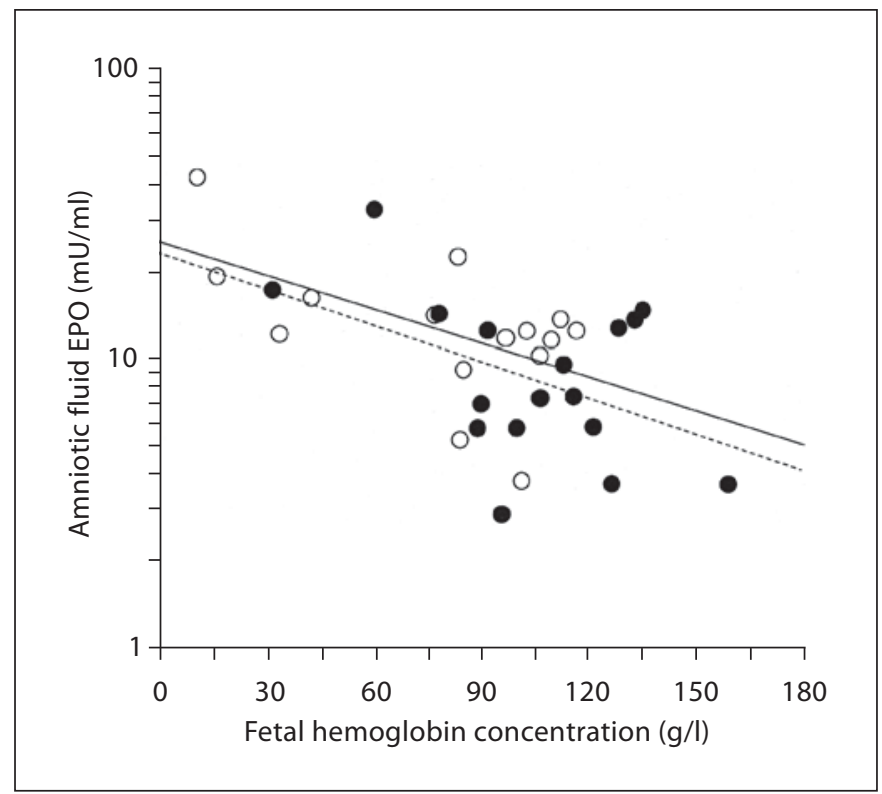

Fig. 5. Negative correlation between fetal hemoglobin concentration and logarithmically transformed amniotic fluid EPO level is the same in fetuses with a gestational age of $<27$ weeks $(\bigcirc$; $\mathrm{r}=-0.57, \mathrm{p}=0.027, \mathrm{n}=15)$ and in fetuses with a gestational age above 27 weeks $(\bullet ; \mathrm{r}=-0.49, \mathrm{p}=0.039, \mathrm{n}=17)$. The regression slopes do not differ from each other. The fetal blood samples were obtained by cordocentesis before the first intrauterine red cell transfusion done for maternal $\mathrm{Rh}$ immunization. Amniotic fluid samples were obtained at the same time as the first cordocentesis.

days after the fetal death suggesting that the fetal demise was acute with insufficient time for the EPO level to increase [36].

\section{Fetal Chronic Anemia}

It has been suggested that fetuses near term have a greater capacity to synthesize EPO during hemolytic anemia than fetuses under 24 weeks of gestation [21]. Our observations differ from those of Moya et al. [21]. We found that the hemoglobin concentration in the fetus and amniotic fluid EPO levels correlated inversely in a similar fashion in fetuses under and above 27 weeks of gestation (fig. 5). The explanation for the difference between our results and those of Moya et al. [21] could be that the cord plasma EPO level was measured only once near term (at birth) in their study. Thus, since some of the older fetuses in the study by Moya et al. [21] may have been chronically hypoxic, this could have increased the fetal EPO synthesis beyond that of fetal anemia alone. Although most of the fetuses in our study were severely anemic (the 
median hemoglobin concentration was $9.8 \mathrm{~g} / \mathrm{dl}$ with a range from 1.1 to $15.9 \mathrm{~g} / \mathrm{dl}$ ), the median of amniotic fluid EPO levels was 11.7 (range 2.8-42.0) $\mathrm{mU} / \mathrm{ml}$. These relatively low levels may be the result of the gradual progressive onset of fetal anemia. Under these chronic conditions, adaptive cardiovascular changes may mitigate the effects of tissue hypoxia. It is also possible that the low EPO levels may be the result of accelerated EPO metabolism in the erythroid progenitor cell pool with high EPO receptor density [81]. Nonetheless, it has been shown that fetuses younger than 30 weeks gestation from pregnancies with severe Rh immunization can markedly increase their amniotic fluid EPO levels when fetal hypoxia acutely worsens [26].

\section{Maternal Smoking and Alcohol Consumption}

In addition to decreasing fetal growth, maternal tobacco smoking increases fetal plasma EPO levels [82-84]. This suggests that maternal smoking results in chronic fetal hypoxemia. Heavy alcohol use (more than $300 \mathrm{~g}$ ethanol/week) during pregnancy results frequently in fetal damage (fetal alcohol syndrome). This amount of maternal alcohol consumption also results in increased cord plasma EPO levels at birth compared to the offspring of mothers with moderate or abstinent alcohol use [85]. Because ethanol infusions into fetal Rhesus monkeys have been shown to result in fetal hypoxemia [86], it seems likely that heavy maternal alcohol use causes chronic fetal hypoxia.

\section{Does the Fetus Increase EPO Production to Protect Its Brain during Hypoxia?}

It was originally thought that the only reason for the increase in EPO synthesis during hypoxia was to increase erythropoiesis for augmenting the oxygen-carrying capacity in the circulation [3]. However, during the last decade, a large number of experimental [87-92] and some clinical studies $[93,94]$ have shown that exogenously administered EPO has also neuroprotective effects related to its anti-apoptotic and vascular growth-promoting properties. EPO treatment has also been shown to reduce vasoconstriction and infarction volume in the brain after hypoxic injury [47]. Since EPO and its receptor are both expressed in glial cells, neurons and endothelial cells of the brain [47], increased endogenous EPO production by the brain is another adaptive mechanism in response to the detrimental effects of hypoxia. EPO also seems to exert a protective role in attenuating the effects of hypoxic insults in other tissues, including peripheral nerves [95], the heart $[96,97]$ and the retina $[98,99]$.

EPO crosses the blood-brain barrier within 2-4 h after exogenous administration of $\mathrm{rHuEPO}$ in the fetal sheep $[100,101]$. This observation is in accordance with both experimental and clinical studies that show a beneficial effect of exogenous rHuEPO on brain tissue after hypoxic insults $[92,102,103]$. When high-dose rHuEPO was administered parenterally to adult humans after stroke, neurologic recovery was better compared to those receiving placebo [93]. In a recent double-masked, randomized controlled study of preterm infants with birth weights of $1,000 \mathrm{~g}$ or less, parenterally administered rHuEPO during the neonatal period resulted in a high serum EPO concentration (500 mU/ml) [94]. The EPO-treated group of preterm infants had a significantly higher mental developmental index at 18-22 months corrected age than those receiving placebo. Multicenter clinical trials have recently been initiated to answer the question whether rHuEPO treatment immediately after birth can improve neurodevelopmental outcomes of very preterm infants $[104,105]$. The results of these studies will determine whether exogenous EPO can be used in the future as a first-line therapeutic agent in fetuses with severe hypoxia.

Based on these considerations, it is plausible that the exponential increase in amniotic fluid EPO concentration observed in hypoxic human fetuses $[26,28,29]$ is the result of a marked increase in placental EPO production, the purpose of which may be to protect the fetal brain from hypoxic damage. More studies are urgently needed to delineate the role and magnitude of placental EPO production.

\section{Clinical Use of Amniotic Fluid and Fetal Plasma EPO Measurements in High-Risk Obstetrics and Neonatology}

Since fetal plasma and amniotic fluid EPO levels increase regardless of the etiology of fetal hypoxia and since high amniotic fluid EPO levels in humans are highly correlated with fetal plasma EPO levels, the presence of chronic or subchronic fetal hypoxia may be assessed by measuring the amniotic fluid EPO concentration. In our experience, the exponential increase observed in amniotic fluid EPO levels in abnormal pregnancies is an alarming signal of imminent serious fetal hypoxia and compromise $[26,29]$. When comparing fetuses with normal $(<20$ $\mathrm{mU} / \mathrm{ml})$ to those with high $(>60 \mathrm{mU} / \mathrm{ml})$ amniotic fluid 
Table 1. Umbilical artery $\mathrm{pH}$ and blood gas values, birth weight $\mathrm{z}$-score and neonatal complications in cases with normal ( $<20 \mathrm{mU} / \mathrm{ml})$ and high (>60 mU/ml) amniotic fluid EPO levels in pregnancies complicated by type-1 diabetes mellitus [28] or hypertension [29]

\begin{tabular}{|c|c|c|c|c|}
\hline & \multicolumn{2}{|c|}{ Type-1 diabetic pregnancies } & \multicolumn{2}{|c|}{ Hypertensive pregnancies } \\
\hline & normal EPO $(n=76)$ & high EPO (n = 21) & normal EPO (n = 38) & high EPO (n = 18) \\
\hline Amniotic fluid EPO, mU/ml & $10.0(2.0-13.4)$ & $153.0(66.0-1,975)$ & $10.4(1.8-19.1)$ & $144.5(74.1-1,512)$ \\
\hline Gestational age, days & $259(212-275)$ & $254(212-271)$ & $253(205-275)$ & $233^{\mathrm{a}}(188-263)$ \\
\hline Birth weight $\mathrm{z}$-score (SD units) & $+1.3(-2.5$ to +6.8$)$ & $+2.8^{\mathrm{c}}(-1.4$ to +6.5$)$ & $-1.6(-4.1$ to +2.1$)$ & $-3.3^{\mathrm{b}}(-4.8$ to -0.3$)$ \\
\hline Umbilical artery $\mathrm{pH}$ & $7.26(7.12-7.32)$ & $7.19^{\mathrm{d}}(7.06-7.26)$ & $7.31(7.19-7.39)$ & $7.23^{\mathrm{d}}(7.09-7.28)$ \\
\hline Umbilical artery $\mathrm{pO}_{2}, \mathrm{kPa}$ & $2.4(1.1-4.2)$ & $1.3^{\mathrm{d}}(0.4-3.5)$ & $2.2(1.3-4.1)$ & $1.6^{\mathrm{c}}(0.5-3.3)$ \\
\hline Umbilical artery base excess, $\mathrm{mEq} / \mathrm{l}$ & $-1.4(-8.3$ to +4.4$)$ & $-2.5^{\mathrm{d}}(-9.6$ to 0.0$)$ & $-1.8(-9.4$ to +3.4$)$ & $-4.0^{\mathrm{c}}(-8.9$ to -1.9$)$ \\
\hline Lowest blood glucose, $\mathrm{mmol} / \mathrm{l}$ & $2.6(1.0-4.2)$ & $1.8^{\mathrm{d}}(0.4-3.2)$ & $2.3(0.5-3.7)$ & $1.0^{\mathrm{d}}(0.2-2.5)$ \\
\hline Cardiomyopathy, \% & 2.6 & $28.6^{\mathrm{d}}$ & - & - \\
\hline Admitted to NICU, \% & 10.5 & $28.6^{\mathrm{a}}$ & 7.9 & $50.0^{c}$ \\
\hline
\end{tabular}

Figure 2 shows amniotic fluid EPO concentrations of the hypertensive pregnancies. 'Normal EPO' is group 1 and 'high EPO' is group 3 in figure 2 . All deliveries were by cesarean section before labor contractions. Results are expressed as median (range) or frequency (\%).

${ }^{\mathrm{a}} \mathrm{p}=0.03 ;{ }^{\mathrm{b}} \mathrm{p}<0.01 ;{ }^{\mathrm{c}} \mathrm{p}<0.001 ;{ }^{\mathrm{d}} \mathrm{p}<0.0001$.

Reproduced with permission [28, 29].

EPO levels, umbilical artery $\mathrm{pH}, \mathrm{pO}_{2}$ and neonatal blood glucose are significantly decreased and umbilical artery base excess increased in those with high amniotic fluid EPO levels (table 1). An amniotic fluid EPO cutoff level of $36 \mathrm{mU} / \mathrm{ml}$ had $56 \%$ sensitivity and $92 \%$ specificity in predicting low umbilical artery $\mathrm{pH}(<7.26)$ at birth and $53 \%$ sensitivity and $82 \%$ specificity for predicting low $\mathrm{pO}_{2}(<12 \mathrm{~mm} \mathrm{Hg})$ in pregnancies complicated by preeclampsia or pregnancy-induced hypertension [29]. In type-1 diabetic pregnancies an amniotic fluid EPO cutoff of $37 \mathrm{mU} / \mathrm{ml}$ had a $49 \%$ sensitivity and $86 \%$ specificity in predicting low umbilical artery $\mathrm{pH}(<7.21)$ at birth and a $53 \%$ sensitivity and $91 \%$ specificity for predicting low $\mathrm{pO}_{2}$ (<15 mm Hg) [28].

We have previously shown that admission to the neonatal intensive care unit was 2.8 times higher in type-1 diabetic pregnancies [28] and 6.3 times higher in hypertensive pregnancies [29] when the amniotic fluid EPO levels obtained within 2 days of delivery were $>60 \mathrm{mU} / \mathrm{ml}$ compared with admissions from pregnancies with normal EPO levels (table 1). Thus, a normal amniotic fluid EPO level may be equally important as a high EPO level in managing high-risk pregnancies as pregnancy may be continued with less concern and concomitant less need for frequent fetal surveillance. While currently available amniotic fluid EPO data may be useful in assessing pregnancies complicated by diabetes, alloimmunization, and fetal growth restriction, similar data from pregnancies at risk of fetal hypoxia from other maternal and fetal causes are needed before considering their clinical application.

To our knowledge, only one follow-up study exists on the clinical significance of high fetal plasma EPO levels at birth on the subsequent outcome of the infant [106]. In this study infants with high cord plasma EPO levels were shown to have poorer outcomes (cerebral palsy or delayed mental development) at 2 years of age compared to infants with low cord plasma EPO levels [106]. In contrast, similar correlations were not found with elevated cord plasma vasopressin or hypoxanthine levels or with metabolic acidosis and low Apgar scores [107]. Clearly more follow-up studies on the long-term outcomes are needed to assess the clinical significance of high amniotic fluid and cord plasma EPO levels in the peripartum period in determining whether EPO is a better indicator of longterm outcomes than cord blood $\mathrm{pH}$, base excess, lactate or low Apgar scores. Amniotic fluid EPO measurements have the advantage that they can be made prior to birth during the time when clinical decision making is ongoing.

Based on available studies, we speculate that amniotic fluid and cord plasma EPO be measured as an adjunct to other clinical and laboratory data whenever amniotic fluid is already being sampled for other purposes, e.g., fetal assessment of lung maturity, chorioamnionitis, etc. To be of clinical value, available EPO assay systems should provide results during the same day of sampling. The defin- 
itive answer of the clinical utility of amniotic fluid and cord plasma EPO measurements in the management of high-risk pregnancies and their offspring must await the results of future sufficiently large controlled studies. Available data indicate that such studies are not only well justified, but are urgently needed.

\section{Acknowledgements}

This work is supported by the United States Public Health Service National Institute of Health grants, P01 HL46925 and R21 GM57367, and grant M01-RR-59 from the National Center for Research Sources, General Clinical Research Center Program.

\section{References}

1 Zanjani ED, Poster J, Burlington H, Mann LI, Wasserman LR: Liver is the primary site of erythropoietin production in the fetus. J Lab Clin Med 1977;77:2497-2503.

$\checkmark 2$ Eckardt KU: The ontogeny of the biological role and production of erythropoietin. J Perinat Med 1995;23:19-29.

3 Moritz KM, Lim GB, Wintour EM: Developmental regulation of erythropoietin and erythropoiesis. Am J Physiol 1997;272: R1829-R1844.

4 Widness JA, Clemons GK, Phillips AF: Erythropoietin levels and erythropoiesis at birth in infants with Potter's syndrome. J Pediatr 1990;117:155-158.

5 Widness JA, Schmidt RL, Sawyer ST: Erythropoietin transplacental passage - review of animal studies. J Perinat Med 1995;23:6170.

-6 Jelkmann W: Erythropoietin: structure, control of production, and function. Physiol Rev 1992;72:449-489.

7 Widness JA, Veng-Pedersen P, Peters C, Pereira LM, Schmidt RL, Lowe LS: Erythropoietin pharmacokinetics in premature infants: developmental, nonlinearity, and treatment effects. J Appl Physiol 1996;80: 140-148.

${ }_{8}$ Widness JA, Veng-Pedersen NB, Modi NB, Schmidt RL, Chestnut DH: Developmental differences in erythropoietin pharmacokinetics: increased clearance and distribution in fetal and neonatal sheep. J Pharmacol Exp Ther 1992;261:977-984.

-9 Eckardt KU, Boutellier U, Kurtz M, Schopen M, Koller EA, Bauer C: Rate of erythropoietin formation in humans in response to acute hypobaric hypoxia. J Appl Physiol 1989;66: 1785-1788.

10 Widness JA, Teramo KA, Clemons GK, Garcia JF, Cavalieri RL, Piasecki GJ, Jackson BT, Susa JB, Schwartz R: Temporal response of immunoreactive erythropoietin to acute hypoxemia in fetal sheep. Pediatr Res 1986; 20:15-19.

11 Kakuya F, Shirai M, Takase M, Ishii N, Okuno A: Effect of hypoxia on amniotic fluid erythropoietin levels in fetal rats. Biol Neonate 1997;72:118-124.
12 Kitanaka T, Alonso JG, Gilbert RD, Siu BL, Clemons GK, Longo LD: Fetal response to long-term hypoxemia in sheep. Am J Physiol 1989;256:R1348-R1354.

13 Widness JA, Clemons GK, Garcia JF, Oh W, Schwartz R: Increased immunoreactive erythropoietin in cord serum after labor. Am J Obstet Gynecol 1984;148:194-197.

14 Clapp JF, Little KD, Appleby-Wineberg SK, Widness JA: The effect of regular maternal exercise on erythropoietin in cord blood and amniotic fluid. Am J Obstet Gynecol 1995 172:1445-1451.

15 Widness JA, Susa JB, Garcia JF, Singer DB, Sehgal P, Oh W, Schwartz R, Schwartz HC: Increased erythropoiesis and elevated erythropoietin in infants born to diabetic mothers and in hyperinsulinemic fetuses. J Clin Invest 1981;67:637-642.

16 Teramo KA, Widness JA, Clemons GK, Voutilainen P, McKinlay S, Schwartz R: Amniotic fluid erythropoietin correlates with umbilical plasma erythropoietin in normal and abnormal pregnancy. Obstet Gynecol 1987;69:710-716.

17 Eckardt KU, Hartmann W, Vetter U, Pohlandt F, Burghardt R, Kurtz A: Serum immunoreactive erythropoietin of children in health and disease. Eur J Pediatr 1990;149: 459-464.

18 Forestier F, Daffos F, Catherine N, Renard M, Adreux JP: Developmental hematopoiesis in normal human fetal blood. Blood 1991; 77:2360-2363.

19 Maier RF, Böhme K, Dudenhausen J, Obladen M: Cord blood erythropoietin in relation to different markers of fetal hypoxia. Obstet Gynecol 1993;81:575-580.

20 Thomas RM, Canning CE, Cotes PM, Linch DC, Rodeck CH, Rossiter CE, Huehns ER: Erythropoietin and cord blood hemoglobin in the regulation of human fetal erythropoiesis. Br J Obstet Gynaecol 1983;90:795-800.

21 Moya FR, Grannum PAT, Widness JA, Clem ons GK, Copel JA, Hobbins JC: Erythropoietin in human fetuses with immune hemolytic anemia and hydrops fetalis. Obstet Gynecol 1993;82:353-358.

-22 Fahnenstich H, Dame C, Alléra A, Kowalewski S: Biochemical monitoring of fetal distress with serum-immunoreactive erythropoietin. J Perinat Med 1996;24:85-91.
23 Finne PH: Erythropoietin levels in cord blood as an indicator of intrauterine hypoxia. Acta Paediatr Scand 1966;55:478-489.

-24 Garcia JF, Ebbe SN, Hollander L, Cutting HO, Miller ME, Cronkite EP: Radioimmunoassay of erythropoietin: circulating levels in normal and polycythemic human beings. J Lab Clin Med 1982;99:624-635.

25 Campbell J, Wathen N, Lewis M, Fingerova $\mathrm{H}$, Chard T: Erythropoietin levels in amniotic fluid and extraembryonic coelomic fluid in the first trimester of pregnancy. Br J Obstet Gynaecol 1992;99:974-976.

26 Voutilainen P, Widness JA, Clemons GK, Schwartz R, Teramo KA: Amniotic fluid erythropoietin predicts fetal distress in Rhimmunized pregnancies. Am J Obstet Gynecol 1989;160:429-434.

-27 Westgren M, Ek S, Remberger M, Ringden O, Stangenberg M: Cytokines in fetal blood and amniotic fluid in Rh-immunized pregnancies. Obstet Gynecol 1995;86:209-213.

28 Teramo K, Kari MA, Eronen M, Markkanen $\mathrm{H}$, Hiilesmaa V: High amniotic fluid erythropoietin levels are associated with an increased frequency of fetal and neonatal morbidity in type 1 diabetic pregnancies. Diabetologia 2004;47:1695-1703.

29 Teramo KA, Hiilesmaa VK, Schwartz R, Clemons GK, Widness JA: Amniotic fluid and cord plasma erythropoietin levels in pregnancies complicated by preeclampsia, pregnancy-induced hypertension and chronic hypertension. J Perinat Med 2004; $32: 240-247$

30 Teramo K: Fetal erythropoietin production increases during hypoxia (in Finnish). Duodecim 2006;122:2619-2627.

-31 Brace RA, Cheung CY, Davis LE, Gagnon R, Harding R, Widness JA: Sources of amniotic fluid erythropoietin during normoxia and hypoxia in fetal sheep. Am J Obstet Gynecol 2006; 195:246-254.

32 Kim MJ, Bogic L, Cheung CY, Brace RA: Placental expression of erythropoietin mRNA, protein and receptor in sheep. Placenta 2001; 22:484-489.

33 Conrad KP, Benyo DF, Westerhausen-Larsen A, Miles TM: Expression of erythropoietin by the human placenta. FASEB J 1996;10:760-766. 
\34 Ogawa A, Terada S, Sakuragawa N, Masuda S, Nagao M, Miki M: Progesterone, but not 17beta-estradiol, up-regulates erythropoietin (EPO) production in human amniotic epithelial cells. J Biosci Bioeng 2003;96:448453.

-35 Biron-Shental T, Schaiff T, Ratjczak CK, Bildirici I, Nelson DM, Sadovsky Y: Hypoxia regulates the expression of fatty acid-binding proteins in primary term human trophoblasts. Am J Obstet Gynecol 2007;197:516. e1-e6.

-36 Teramo KA, Schwartz R, Clemons GK, Widness JA: Amniotic fluid erythropoietin concentrations differentiate between acute and chronic causes of fetal deaths. Acta Obstet Gynecol Scand 2002;81:245-251.

-37 Schmidt NM, Schmidt RA, Teramo KA, Widness JA: Endogenous and recombinant erythropoietin levels decline in human amniotic fluid and fetal plasma in vitro at $37^{\circ} \mathrm{C}$. J Perinatology 2004;24:218-222.

-38 Snijders RJM, Abbas A, Melby O, Ireland RM, Nicolaides KH: Fetal plasma erythropoietin in severe growth retardation. Am J Obstet Gynecol 1993;168:615-619.

-39 Vora M, Gruslin A: Erythropoietin in obstetrics. Obstet Gynecol Surv1998;53:500508.

40 Widness JA, Teramo KA: Erythropoietin: significance as an indicator of fetal pathology; in Kurjak A (ed): Textbook of Perinatal Medicine: A Comprehensive Guide to Modern Clinical Perinatology. London, Parthenon, 1998, pp 549-558.

-41 Hanion-Lundberg KM, Kirby RS, Gandhi S, Broekhuizen FF: Nucleated red blood cells in cord blood of singleton term neonates. Am J Obstet Gynecol 1997;176:1149-1154.

-42 Spencer MK, Khong TY, Matthews BL, MacLennan AH: Haematopoietic indicators of fetal metabolic acidosis. Aust NZ J Obstet Gynaecol 2000;40:286-289.

-43 Korst LM, Phelan JP, Ahn MO, Martin GL: Nucleated red blood cells: an update on the marker for fetal asphyxia. Am J Obstet Gynecol 1996;175:843-846.

-44 Ferber A, Fridel Z, Weissmann-Brenner A, Minior VK, Divon MY: Are elevated fetal nucleated red blood cell counts an indirect reflection of enhanced erythropoietin activity? Am J Obstet Gynecol 2004;190:14731475.

-45 Semenza GL: Regulation of mammalian $\mathrm{O}_{2}$ homeostasis by hypoxia-inducible factor 1 . Annu Rev Cell Dev Biol 1999;15:551-578.

46 Wenger RH: Cellular adaptation to hypoxia: $\mathrm{O}_{2}$-sensing protein hydroxylases, hypoxiainducible transcription factors, and $\mathrm{O}_{2}$-regulated gene expression. FASEB J 2002;16: 1151-1162.

47 Marti HH: Erythropoietin and the hypoxic brain. J Exp Biol 2004;207:3233-3242.
48 Davis LE, Widness JA, Brace RA: Renal and placental secretion of erythropoietin during anemia or hypoxia in the ovine fetus. Am J Obstet Gynecol 2003;189:1764-1770.

49 Shannon K, Davis JC, Kitzmiller JL, Fulcher SA, Koenig HM: Erythropoiesis in infants of diabetic mothers. Pediatr Res 1986;20:161165.

50 Rollins MD, Maxwell AP, Afrasiabi M, Halliday HL, Lappin TRJ: Cord blood erythropoietin, $\mathrm{pH}, \mathrm{PaO}_{2}$ and haematocrit following caesarean section before labour. Biol Neonate 1993;63:147-152.

-51 Stangenberg M, Legarth J, Hong-Lie C, Lingman G, Persson B, Rahman F, Westgren M: Erythropoietin concentrations in amniotic fluid and umbilical venous blood from Rhimmunized pregnancies. J Perinat Med 1993; 21:225-234

52 Buescher U, Hertwig K, Wolf C, Dudenhausen JW: Erythropoietin in amniotic fluid as a marker of chronic fetal hypoxia. Int J Gynecol Obstet 1998;60:257-263.

53 Phillips AF, Widness JA, Garcia JF, Raye JR, Schwartz R: Erythropoietin in the chronically hyperglycemic fetal lamb. Proc Soc Exp Biol Med 1982;170:42-47.

54 Georgieff MK, Schmidt RL, Mills MM, Radmer WJ, Widness JA: Fetal iron and cytochrome $c$ status after intrauterine hypoxemia and erythropoietin administration. Am J Physiol 1992;262:R485-R491.

55 Petry CD, Eaton MA, Wobken JD, Mills MM, Johnson DE, Georgieff MK: Iron deficiency of liver, heart, and brain in newborn infants of diabetic mothers. J Pediatr 1992; 121:109-114.

56 Lott DG, Zimmerman B, Labbé RF, Kling PJ, Widness JA: Erythrocyte zinc protoporphyrin is elevated with prematurity and fetal hypoxemia. Pediatrics 2005;116:414-422.

57 Lozoff B, Beard J, Connor J, Felt B, Georgieff M, Schallert T: Long-lasting neural and behavioral effects of iron deficiency in infancy. Nutr Rev 2006;64:S34-S43.

58 Jazayeri A, Tsibris JC, Spellacy WN: Elevated umbilical cord plasma erythropoietin levels in prolonged pregnancies. Obstet Gynecol 1998;92:61-63.

59 Richey SD, Ramin SM, Bawdon RE, Roberts SW, Dax J, Roberts J, Gilstrap LC: Markers of acute and chronic asphyxia in infants with meconium-stained amniotic fluid. Am J Obstet Gynecol 1995;172:1212-1215.

60 Manchada R, Vora M, Gruslin A: Influence of postdatism and meconium on fetal erythropoietin. J Perinatol 1999;19:479-482

-61 Jazayeri A, Politz L, Tsibris JC, Queen T, Spellacy WM: Fetal erythropoietin levels in pregnancies complicated by meconium passage: does meconium suggest fetal hypoxia? Am J Obstet Gynecol 2000;183:188-190.
62 Lemery DJ, Santolaya J, Serre AF, Denoix S, Besse GH, Vanlieferinghen PC, Bezou MJ, Gaillard G, Jacquetin B: Serum erythropoietin in small for gestational age fetuses. Biol Neonate 1994;65:89-93.

63 Doi S, Osada H, Seki K, Sekiya S: Relationship of amniotic fluid index and cord blood erythropoietin levels in small for and appropriate for gestational age fetuses. Obstet Gynecol 1999;94:768-772.

64 Jazayeri A, Tsibris JC, Spellacy WN: Fetal erythropoietin levels in growth-restricted and appropriately grown neonates with and without abnormal fetal heart rate tracings: a comparison with cord blood gases and Apgar scores. J Perinatol 1999;19:255-259.

65 Morley R, Moore VM, Dwyer T, Owens JA, Umstad MP, Carlin JB: Association between erythropoietin in cord blood of twins and size at birth: does it relate to gestational factors or to factors during labor or delivery. Pediatr Res 2005;57:680-684.

-66 Lemery DR, Santolaya-Forgas J, Serre AF, Besse GH, Jacquetin B: Fetal serum erythropoietin in twin pregnancies with discordant growth. Fetal Diagn Ther 1995;10:86-91.

-67 Maier RF, Bialobrzeski B, Gross A, Vogel M, Dudenhausen JW, Obladen M: Acute and chronic fetal hypoxia in monochorionic and dichorionic twins. Obstet Gynecol 1995;86: 973-977.

68 Zamudio S, Baumann MU, Illsley NP: Effects of chronic hypoxia in vivo on the expression of human placental glucose transporters. Placenta 2006;27:49-55

-69 Widness JA, Teramo KA, Clemons GK, Coustan DR, Cavalieri RL, Oh W, Welch GP, Schwartz R: Correlation of the interpretation of fetal heart rate records with cord plasma erythropoietin levels. Br J Obstet Gynaecol 1985;92:326-332.

70 Kakuya F, Shirai M, Takase M, Ishii N, Ishioka T, Hayashi T, Kasamo M, Kawamura M, Sasaki K: Relationship between erythropoietin levels both in cord serum and amniotic fluid at birth and abnormal fetal heart rate records. Pediatr Int 2002;44:414-419.

71 Clapp JF, Lopez B, Simonean S: Nuchal cord and neurodevelopmental performance at 1 year. J Soc Gynecol Investig 1999;6:268-272.

72 Hashimoto K, Clapp JF: The effect of nuchal cord on amniotic fluid and cord blood erythropoietin at delivery. J Soc Gynecol Investig 2003;10:406-411.

73 Girsen A, Mäkikallio K, Hiilesmaa V, Hämäläinen E, Teramo K, Räsänen J: The relationship between human fetal cardiovascular hemodynamics and serum erythropoietin levels in growth-restricted fetuses. Am J Obstet Gynecol 2007;196:467.e1-e6.

74 Casson IF, Clarke CA, Howard CV, McKendrick O, Pennycook S, Pharoah PO, Platt MJ, Stannisstreet M, van Velszen D, Walkinshaw S: Outcomes of pregnancy in insulin dependent diabetic women: results of a five year population cohort study. BMJ 1997;315:275278 . 
75 Lauenborg J, Mathiesen E, Ovesen P, Westergaard JG, Ekbom P, Molsted-Pedersen L, Damm P: Audit on stillbirths in women with pregestational type 1 diabetes. Diabetes Care 2003;26:1385-1389.

-76 Madsen H: Fetal oxygenation in diabetic pregnancy. With special reference to maternal blood oxygen affinity and its effectors. Dan Med Bull 1986;33:64-74.

-77 Carson BS, Philips AF, Simmons MA, Battaglia FC, Meschia G: The effects of sustained insulin infusion upon glucose uptake and oxygenation in the ovine fetus. Pediatr Res 1980;14:147-152.

-78 Milley JR, Rosenberg AA, Philips AF, Molteni RA, Jones MD, Simmons MA: The effect of insulin on ovine fetal oxygen extraction. Am J Obstet Gynecol 1984;149:673-678.

79 Widness JA, Teramo KA, Clemons GK, Voutilainen P, Stenman UH, McKinlay SM, Schwartz R: Direct relationship of antepartum glucose control and fetal erythropoietin in human type 1 (insulin-dependent) diabetic pregnancy. Diabetologia 1990;9:75-79.

-80 Kim SJ, Cheung CY, Widness JA, Brace RA: Temporal response of plasma erythropoietin to hemorrhage in the ovine fetus. J Soc Gynecol Investig 2002;9:75-79.

-81 Freise KJ, Widness JA, Segar JL, Schmidt RL, Veng-Pedersen P: Increased erythropoietin elimination in fetal sheep following chronic phelobotomy. Pharm Res 2007;24:16531659.

-82 Varvarigou A, Beratis NG, Makri M, Vagenakis AG: Increased levels and positive correlation between erythropoietin and hemoglobin concentrations in newborn children of mothers who are smokers. J Pediatr 1994;124:480-482.

-83 Bili H, Mamopoulos M, Tsantali C, Tzevelekis P, Malaka K, Mantalenakis S, Farmakides G: Elevated umbilical erythropoietin levels during labor in newborns of smoking mothers. Am J Perinatol 1996;13:85-87.

-84 Ingvarsson RF, Bjarnason AO, Dagbjartsson A, Hardardottir H, Haraldsson A, Thorkelsson $\mathrm{T}$ : The effects of smoking in pregnancy on factors influencing fetal growth. Acta Paediatr 2007;96:383-386.

85 Halmesmäki E, Teramo KA, Widness JA, Clemons GK, Ylikorkala O: Maternal alcohol abuse is associated with elevated erythropoietin levels. Obstet Gynecol 1990;76: 219-222.
86 Horiguchi T, Suzuki K, Comas-Urrutia AC, Mueller-Heubach E, Boyer-Milic AM, Baratz RA, Morishima HO, James LS, Adamsons K Effect of ethanol upon uterine activity and fetal acid-base state of the rhesus monkey. Am J Obstet Gynecol 1971;109:910-917.

87 Sakanaka M, Wen TC, Matsuda S, Masuda S, Morishita E, Nagao M, Sasaki R: In vivo evidence that erythropoietin protects neurons from ischemic damage. Proc Natl Acad Sci USA 1998;95:4635-4640.

88 Sirén AL, Fratelli M, Brines M, Goemans C, Casagrande S, Lewczuk P, Keenan S, Gleiter C, Pasquali C, Capobianco A, Mennini T, Heumann R, Cerami A, Ehrenreich $\mathrm{H}$, Ghezzi P: Erythropoietin prevents neuronal apoptosis after cerebral ischemia and metabolic stress. Proc Natl Acad Sci USA 2001;98: 4044-4049.

89 Wen TC, Sadamoto Y, Tanaka J, Zhu PX, Nakata K, Ma YJ, Hata R, Sakanaka M: Erythropoietin protects neurons against chemical hypoxia and cerebral ischemic injury by upregulating Bcl-xL expression. J Neurosci Res 2002;67:795-803.

90 Chong ZZ, Kang JQ, Maiese K: Erythropoietin fosters both intrinsic and extrinsic neuronal protection through modulation of $\mathrm{mi}$ croglia, Akt1, Bad, and caspase-mediated pathways. Br J Pharmacol 2003;138:11071118.

91 McPherson RJ, Demers EJ, Juul SE: Safety of high-dose recombinant erythropoietin in a neonatal rat model. Neonatology 2007;91: $36-43$

92 Kumral A, Baskin H, Yesilirmak DC, Ergur BU, Aykan S, Genc S, Genc K, Yilmaz O, Tugyan K, Giray O, Duman N, Ozkan H: Erythropoietin attenuates lipopolysaccharide-induced white matter injury in the neonatal rat brain. Neonatology 2007;92:269-278.

93 Ehrenreich H, Hasselblatt M, Dembowski C, Cepek L, Lewczuk P, Stiefe M, Rustenbeck HH, Breiter N, Jacob S, Knerlich F, Bohn M, Poser W, Ruether E, Kochen M, Gefeller O, Gleiter C, Wessel TC, De Ryck M, Itri L, Prange H, Cerami A, Brines M, Siren AL: Erythropoietin therapy for acute stroke is both safe and beneficial. Mol Med 2002;8: 495-505.

94 Bierer R, Peceny C, Hartenberger CH, Ohls RK: Erythropoietin concentrations and neurodevelopmental outcome in preterm infants. Pediatrics 2006;118:635-640.

$\$ 95$ Höke A, Keswani SC: Neuroprotection in the PNS: erythropoietin and immunophilin ligands. Ann NY Acad Sci 2005; 1053:491501.

-96 Cai Z, Manalo DJ, Wei G, Rodriguez ER, FoxTalbot K, Lu H, Zweier JL, Semenza GL: Hearts from rodents exposed to intermittent hypoxia or erythropoietin are protected against ischemia-reperfusion injury. Circulation 2003;108:79-85.
$\$ 97$ Bogoyevitch MA: An update on the cardiovascular effects of erythropoietin cardioprotection by erythropoietin and the lessons learnt from studies in neuroprotection. Cardiovasc Res 2004;63:208-216.

98 Junk AK, Mammis A, Savitz SI, Singh M, Malhotra S, Rosenbaum PS, Cerami A, Brines M, Rosenbaum DM: Erythropoietin administration protects retinal neurons from acute ischemia-reperfusion injury. Proc Natl Acad Sci USA 2002;99:1065910664.

\$9 Weishaupt JH, Rohde G, Pölking E, Siren AL, Ehrenreich H, Bähr M: Effect of erythropoietin axotomy-induced apoptosis in rat retinal ganglion cells. Invest Ophthalmol Vis Sci 2004;45:1514-1522.

100 Brines ML, Ghezzi P, Keenan S, Agnello D, de Lanerolle NC, Cerami C, Itri LM, Cerami A: Erythropoietin crosses the bloodbrain barrier to protect against experimental brain injury. Proc Natl Acad Sci USA 2000;97:10526-10531

101 Juul SE, McPherson RJ, Farrell FX, Jolliffe L, Ness DJ, Gleason CA: Erythropoietin concentrations in cerebrospinal fluid of nonhuman primates and fetal sheep following high-dose recombinant-erythropoietin. Biol Neonate 2004;85:138-144.

102 Demers EJ, McPhaerson RJ, Juul SE: Erythropoietin protects dopaminergic neurons and improves neurobehavioral outcomes in juvenile rats after neonatal hypoxia-ischemia. Pediatr Res 2005;58:297-301.

103 Kellert BA, McPherson RJ, Juul SE: A comparison of high-dose recombinant erythropoietin treatment regimens in brain-injured neonatal rats. Pediatr Res 2007;61: 451-455.

104 Swiss Neonatal Network: Does erythropoietin improve outcome in very preterm infants? Published online at http:// clinicaltrials.gov/ct/show/NCT00413946? order $=1,2006$

105 Fauchére JC, Dame C, Vonthein R, Koller B, Sandra A, Martin W, et al: An approach to use recombinant erythropoietin for neuroprotection in very preterm infants. Acta Paediatr 2007;96:456.

106 Ruth V, Autti-Rämö I, Granström ML, Korkman M, Raivio KO: Prediction of perinatal brain damage by cord plasma vasopressin, erythropoetin, and hypoxanthine values. J Pediatr 1988;113:880-885.

107 Ruth VJ, Raivio KO: Perinatal brain damage: predictive value of metabolic acidosis and the Apgar score. BMJ 1988;297:24-27. 